\title{
Surgical cure rates of sporadic medullary thyroid cancer in the era of calcitonin screening
}

\author{
Andreas Machens ${ }^{1}$ and Henning Dralle ${ }^{1,2}$ \\ ${ }^{1}$ Department of General, Visceral and Vascular Surgery, Medical Faculty, Martin-Luther-University \\ Halle-Wittenberg, Halle (Saale), Germany and 'Department of General, Visceral and Transplantation \\ Surgery, Section of Endocrine Surgery, University of Duisburg-Essen, Essen, Germany
}

Correspondence should be addressed to A Machens

Email

AndreasMachens@aol.com

\begin{abstract}
Objective: Time trends of the extent of disease at first diagnosis and biochemical cure remain ill-defined for sporadic medullary thyroid cancer (MTC). This investigation aimed to delineate time trends and biochemical cure rates for sporadic MTC.

Design: This was an observational study of consecutive patients operated on for sporadic MTC between 1995 and 2015. Methods: Time trends of clinical and histopathological variables indicative of the extent of disease and biochemical cure were calculated for 600 patients with sporadic MTC, 322 of whom had initial neck surgery and 278 of whom had neck reoperation at a tertiary surgical center in Germany.

Results: From 1995-2000 to 2011-2015, significant declines (all $P<0.001$ ) were noted in the percentage of node-positive tumors (from 73 to $49 \%$ ), mediastinal lymph node metastasis (from 21 to $6 \%$ ) and distant metastasis (from 23 to $6 \%$ ). These changes were paralleled by significant increases (all $P<0.001$ ) in mean patient age (from 49.1 to 57.3 years) and the percentage of MTC $\leq 10 \mathrm{~mm}$ (from 19 to $39 \%$ ) and biochemical cure (from 28 to $62 \%$ ). When only patients with primary tumors $>10 \mathrm{~mm}$ were considered, the decreasing percentage of mediastinal lymph node metastasis and distant metastasis, and rising mean patient age and biochemical cure rates remained statistically significant.

Conclusions: Significant reductions in the extent of the disease and improved biochemical cure rates pointed toward increasing therapeutic control of sporadic MTC. The independent contribution of routine
\end{abstract} calcitonin screening to these time-dependent changes warrants more research.

\section{Introduction}

The proliferation of advanced technology, enabling powerful screening programs and better clinical outcomes, has revolutionized the practice of medicine. Establishing a diagnosis of cancer before the operation is considered to lead to oncologically more adequate surgical interventions and improved cure rates (1). An assumption underlying many screening programs is that detection of subclinical, asymptomatic disease at the beginning of the cancer growth trajectory of sequential spread of cancer from a single focus to lymph nodes and distant organs allows for surgical removal of the tumor before it spreads further to produce clinical signs and symptoms (2).

www.eje-online.org DOI: 10.1530/EJE-16-0325
() 2016 European Society of Endocrinology Printed in Great Britain
For follicular cell-derived thyroid cancer, the resultant transformation of the clinical landscape is epitomized by the recent epidemic of occult papillary thyroid cancer (3), owing to overdiagnosis of clinically irrelevant nodules triggered by high-resolution ultrasonography (4). This transformation exacted changes in management strategies for papillary thyroid cancer toward personalized medicine based on individual risk assessment. For sporadic medullary thyroid cancer (MTC), a calcitoninsecreting neuroendocrine malignancy, time trends of the extent of disease at first diagnosis and biochemical cure (postoperative normalization of raised calcitonin

Published by Bioscientifica Ltd. 
serum levels) have not been delineated in depth. Because of its fairly slow growth rate, a small MTC is believed to take 10years or longer to surface on imaging (5), opening a window of opportunity for preemptive surgery.

Although high-resolution ultrasonography has been well established by the mid-1990s throughout the Western hemisphere, biochemical (calcitonin) screening started gathering momentum with the expanding use of sensitive commercial assays specific for monomeric calcitonin after a series of publications in the late 1990s advocating its routine use $(6,7,8,9,10)$. This prompted the German Society for Endocrinology Thyroid Group in 2004 (11), followed by an interdisciplinary European consensus group in 2006 (12), to recommend calcitonin screening in patients with nodular thyroid disease. These recommendations have been greeted with less enthusiasm in some parts of the world because of lingering concerns regarding cost-effectiveness, prompting the revised American Thyroid Association guidelines to recommend neither for nor against the routine use of calcitonin screening in patients with nodular goiters (13).

Because biochemical (calcitonin) screening is more sensitive than fine-needle aspiration cytology $(14,15)$ or ultrasonography (16), the widespread use and coverage of calcitonin screening programs by private and statutory health insurance plans in Germany is set to have changed the scene for sporadic MTC. Unpublished data from the German Prospective Evaluation Thyroid Surgery 2 (PETS2) observational study of 22011 patients operated on for thyroid disease between 2010 and 2013 at 68 surgical departments indicate that $49.7 \%$ of patients with thyroid disease are being subjected to calcitonin screening in Germany (Henning Dralle, personal communication).

To define time trends of the extent of disease at first diagnosis and biochemical cure for sporadic MTC, the present investigation was set up at the largest tertiary referral center dedicated to thyroid cancer surgery in Germany.

Table 1 Overall time trends of sporadic medullary thyroid cancer.

\begin{tabular}{|c|c|c|c|c|c|c|}
\hline & \multirow[b]{2}{*}{ Total } & \multicolumn{4}{|c|}{ Period of thyroidectomy } & \multirow[b]{2}{*}{$\boldsymbol{P}_{\text {trend }}$} \\
\hline & & 1995-2000 & 2001-2005 & 2006-2010 & 2011-2015 & \\
\hline No. of patients & 600 & 131 & 155 & 172 & 142 & \\
\hline $\begin{array}{l}\text { No. of patients with } \\
\text { thyroidectomy at the } \\
\text { authors' institution }\end{array}$ & $322(54)$ & $38(29)$ & $78(50)$ & $103(60)$ & $103(73)$ & $<0.001$ * \\
\hline $\begin{array}{l}\text { No. of patients with } \\
\text { thyroidectomy elsewhere }\end{array}$ & $278(46)$ & $93(71)$ & $77(50)$ & $69(40)$ & $39(27)$ & \\
\hline $\begin{array}{l}\text { Age at onset, y, mean } \\
(95 \% \mathrm{Cl})\end{array}$ & $52.8(51.6 ; 53.9)$ & $49.1(46.8 ; 51.4)$ & $50.5(48.0 ; 52.9)$ & $53.8(51.7 ; 55.9)$ & $57.3(54.9 ; 59.7)$ & $<0.001$ * \\
\hline $\begin{array}{l}\text { Gender, no. of male } \\
\text { patients }\end{array}$ & $280(47)$ & $63(48)$ & $61(39)$ & $85(49)$ & $71(50)$ & 0.36 \\
\hline $\begin{array}{l}\text { Primary tumor diameter, } \\
\mathrm{mm} \text { mean }(95 \% \mathrm{Cl})^{\dagger}\end{array}$ & $21.8(20.4 ; 23.2)$ & $23.6(20.8 ; 26.4)$ & $22.6(19.7 ; 25.5)$ & $20.6(18.4 ; 22.9)$ & $20.8(17.4 ; 24.1)$ & 0.40 \\
\hline $\begin{array}{l}\text { No. of patients with MTC } \\
\leq 10 \mathrm{~mm}^{+}\end{array}$ & $162(29)$ & $23(19)$ & $37(26)$ & $46(28)$ & $56(39)$ & $<0.001 *$ \\
\hline $\begin{array}{l}\text { No. of patients with } \\
\text { extrathyroidal tumor } \\
\text { extension }\end{array}$ & $148(25)$ & $30(23)$ & $40(26)$ & $45(26)$ & $33(23)$ & $>0.99$ \\
\hline $\begin{array}{l}\text { No. of patients with } \\
\text { node-positive MTC }\end{array}$ & $360(60)$ & $95(73)$ & $92(59)$ & $104(60)$ & $69(49)$ & $<0.001 *$ \\
\hline $\begin{array}{l}\text { No. of patients with } \\
\text { mediastinal lymph node } \\
\text { metastasis }\end{array}$ & $71(12)$ & $27(21)$ & $19(12)$ & $17(10)$ & $8(6)$ & $<0.001 *$ \\
\hline $\begin{array}{l}\text { No. of patients with distant } \\
\text { metastasis }\end{array}$ & $97(16)$ & $30(23)$ & $38(25)$ & $20(12)$ & $9(6)$ & $<0.001 *$ \\
\hline $\begin{array}{l}\text { No. of patients with } \\
\text { postoperative biochemical } \\
\text { cure }^{\S}\end{array}$ & $236(45)$ & $28(28)$ & $57(41)$ & $71(45)$ & $80(62)$ & $<0.001 *$ \\
\hline
\end{tabular}

Numbers in parentheses denote the percentage of patients in the respective time period.

* Significant after Bonferroni correction for multiple testing; ${ }^{\dagger}$ Excluding 32 patients $(9,14,9$ and 0 patients) who had no pertinent information; ${ }^{\ddagger}$ Excluding 7 patients (2, 4, 1 and 0 patients) who had no pertinent information; ' Excluding 70 patients (30, 15, 13 and 12 patients) who had no raised calcitonin levels and/or no pertinent postoperative information. 


\section{Patients and methods}

\section{Study population}

This retrospective investigation included 600 consecutive patients with sporadic MTC referred for initial neck surgery (322 patients; 54\%) or reoperation (278 patients; 46\%) between January 1995 and December 2015 from within Germany. Informed consent was obtained before each operation that represented standard practice of care in accordance with the practice guidelines of the German Cancer Association (17).

All 600 patients had total thyroidectomy with systematic lymph node dissection at this or an outside institution. The extent of lymph node dissection depended on the patient's basal calcitonin serum level $(18,19)$ and suspicion or confirmation of nodal disease on clinical workup by imaging ( $\mathrm{cN} 1)$ and/or biopsy or during the operation by surgical exploration and frozen section. To obtain information on the necessary extent of reoperation (systematic lymph node dissection vs focused surgical approach directed at target lesions delineated on imaging) at the authors' institution, outside pathology reports were reviewed for the number of nodes removed elsewhere from the central, lateral and upper mediastinal compartments (19). Calcitonin screening was employed routinely in the 322 patients with thyroidectomy at the authors' institution and all our patients undergoing reoperation for thyroid cancer. In the 278 patients who had thyroidectomy elsewhere and on average were referred 24.3 months later to the authors' institution for reoperation, information about initial preoperative biochemical screening at the referring institutions or other third-party facilities was not always forthcoming but overall appeared to have been lower.

For retrospective analysis of existing data sets from routine patient care, no institutional review board approval is required under German law and applicable institutional regulations.

\section{RET gene analysis}

To rule out the presence of RET germline mutations, genomic DNA was purified from peripheral blood leukocytes using standard techniques. Genomic DNA was amplified using PCR and oligonucleotide primers for exons $10,11,13,14,15$, and 16. Single-strand conformation polymorphism analysis and direct sequencing were performed according to national laboratory and genetic

Table 2 Time trends of sporadic medullary thyroid cancer treated first at the authors' institution.

\begin{tabular}{|c|c|c|c|c|c|c|}
\hline & \multirow[b]{2}{*}{ Total } & \multicolumn{4}{|c|}{ Period of initial thyroidectomy } & \multirow[b]{2}{*}{$\boldsymbol{P}_{\text {trend }}$} \\
\hline & & 1995-2000 & 2001-2005 & 2006-2010 & 2011-2015 & \\
\hline No. of patients & 322 & 38 & 78 & 103 & 103 & \\
\hline $\begin{array}{l}\text { Age at onset, } y \text {, mean } \\
(95 \% \mathrm{Cl})\end{array}$ & $56.2(54.7 ; 57.7)$ & $53.5(48.9 ; 58.0)$ & $53.6(50.1 ; 57.0)$ & $56.5(54.0 ; 59.0)$ & $58.8(56.1 ; 61.6)$ & 0.050 \\
\hline Gender, no. of male patients & $149(46)$ & $19(50)$ & $35(45)$ & $46(45)$ & $49(48)$ & $>0.99$ \\
\hline $\begin{array}{l}\text { Primary tumor diameter, } \mathrm{mm} \\
\text { mean }(95 \% \mathrm{Cl})^{\dagger}\end{array}$ & $19.1(17.1 ; 21.1)$ & $26.1(19.5 ; 32.7)$ & $19.9(15.7 ; 24.1)$ & $15.3(12.9 ; 17.8)$ & $19.7(15.7 ; 23.7)$ & 0.018 \\
\hline $\begin{array}{l}\text { No. of patients with MTC } \\
\leq 10 \mathrm{~mm}^{\dagger}\end{array}$ & $123(40)$ & $8(23)$ & $28(38)$ & $41(43)$ & $46(45)$ & 0.037 \\
\hline $\begin{array}{l}\text { No. of patients with } \\
\text { extrathyroidal tumor } \\
\text { extension }{ }^{\ddagger}\end{array}$ & $68(21)$ & $12(32)$ & $17(22)$ & $21(21)$ & $18(17)$ & 0.10 \\
\hline $\begin{array}{l}\text { No. of patients with } \\
\text { node-positive MTC }\end{array}$ & $131(41)$ & $18(47)$ & $34(44)$ & $41(40)$ & $38(37)$ & 0.22 \\
\hline $\begin{array}{l}\text { No. of patients with } \\
\text { mediastinal lymph node } \\
\text { metastasis }\end{array}$ & $25(8)$ & $8(21)$ & $6(8)$ & $6(6)$ & $5(5)$ & 0.007 \\
\hline $\begin{array}{l}\text { No. of patients with distant } \\
\text { metastasis }\end{array}$ & $37(11)$ & $9(24)$ & $15(19)$ & $8(8)$ & $5(5)$ & $<0.001$ * \\
\hline $\begin{array}{l}\text { No. of patients with } \\
\text { postoperative biochemical } \\
\text { cure }^{\S}\end{array}$ & $188(64)$ & $16(53)$ & $41(57)$ & $62(64)$ & $69(73)$ & 0.016 \\
\hline
\end{tabular}

Numbers in parentheses denote the percentage of patients in the respective time period.

*Significant after Bonferroni correction for multiple testing; ${ }^{\dagger}$ Excluding 14 patients (3, 4, 7 and 0 patients) who had no pertinent information; ${ }^{\ddagger}$ Excluding 2 patients (0, 1, 1 and 0 patients) who had no pertinent information; ${ }^{\S}$ Excluding 28 patients $(8,6,6$ and 8 patients) who had no raised calcitonin levels and/or no pertinent postoperative information. 
regulations for RET analysis (20). Before undergoing genetic testing before or after the operation to exclude hereditable disease, all patients had given informed consent after genetic counseling.

\section{Extent of surgery}

The central neck compartment, extending vertically from the hyoid bone to the thoracic inlet and horizontally between the carotid sheaths, was dissected in 554 (92\%) patients (296 patients with initial surgery and 258 reoperated patients) using the compartment-oriented approach (21). The lateral compartments, spreading laterally from the carotid sheath to the trapezius muscle and inferiorly from the subclavian vein to the hypoglossal nerve superiorly, were dissected systematically in 497 (83\%) patients (267 patients with initial surgery and 230 reoperated patients) on the side of the primary tumor and in 415 (69\%) patients (234 patients with initial surgery and 181 reoperated patients) on the opposite side. The mediastinal compartment, stretching between the brachiocephalic vein and tracheal bifurcation, was dissected by complete median sternotomy in 83 (14\%) patients (37 patients with initial surgery and 46 reoperated patients).

All operations were conducted using optical magnification and bipolar coagulation, as described previously (22). Furthermore, intermittent intraoperative nerve monitoring was implemented at the authors' institution in December 1997 as a standard of care complementing visual nerve identification.

\section{Histopathological examination of surgical specimens}

Conventional staining with hematoxylin and eosin and calcitonin immunohistochemical analysis involving a standard immunoperoxidase technique were performed. A diagnosis of MTC was typically based on evidence of extension beyond the basement membrane, demonstration of lymphatic or vascular invasion on histopathological analysis, or both findings according to the World Health Organization's International Histological Classification of Tumours $(23,24)$. Primary tumor diameter was ascertained by direct measurements on the thyroid specimens. When multiple tumor foci were present, only the size of the largest lesion was taken. All lymph node metastases were diagnosed on histopathologic analysis using conventional methodology. Pathology reports from outside operations were reviewed as well.

\section{Follow-up and biochemical cure}

The diagnosis of distant metastasis was based on radiological evidence on ultrasonography, computed

Table 3 Time trends of sporadic medullary thyroid cancer treated first elsewhere.

\begin{tabular}{|c|c|c|c|c|c|c|}
\hline & \multirow[b]{2}{*}{ Total } & \multicolumn{4}{|c|}{ Period of initial thyroidectomy } & \multirow[b]{2}{*}{$\boldsymbol{P}_{\text {trend }}$} \\
\hline & & 1995-2000 & $2001-2005$ & $2006-2010$ & $2011-2015$ & \\
\hline No. of patients & 278 & 93 & 77 & 69 & 39 & \\
\hline Age at onset, $y$, mean $(95 \% \mathrm{Cl})$ & $48.8(47.1 ; 50.4)$ & $47.4(44.7 ; 50.0)$ & $47.3(44.0 ; 50.6)$ & $49.8(46.4 ; 53.2)$ & $53.2(48.4 ; 58.0)$ & 0.11 \\
\hline Gender, no. of male patients & $131(47)$ & $44(47)$ & $26(34)$ & $39(57)$ & $22(56)$ & 0.12 \\
\hline $\begin{array}{l}\text { Primary tumor diameter, } \mathrm{mm} \\
\text { mean }(95 \% \mathrm{Cl})^{\dagger}\end{array}$ & $25.0(23.1 ; 26.9)$ & $22.6(19.6 ; 25.5)$ & $25.6(21.6 ; 29.6)$ & $28.2(24.6 ; 31.8)$ & $23.6(17.5 ; 29.6)$ & 0.15 \\
\hline $\begin{array}{l}\text { No. of patients with MTC } \\
\leq 10 \mathrm{~mm}^{+}\end{array}$ & $39(15)$ & $15(17)$ & $9(13)$ & $5(7)$ & $10(26)$ & 0.87 \\
\hline $\begin{array}{l}\text { No. of patients with } \\
\text { extrathyroidal tumor } \\
\text { extension }\end{array}$ & $80(29)$ & $18(20)$ & $23(31)$ & $24(35)$ & $15(38)$ & 0.014 \\
\hline $\begin{array}{l}\text { No. of patients with } \\
\text { node-positive MTC }\end{array}$ & $229(82)$ & 77 (83) & $58(75)$ & $63(91)$ & 31 (79) & 0.60 \\
\hline $\begin{array}{l}\text { No. of patients with mediastinal } \\
\text { lymph node metastasis }\end{array}$ & 46 (17) & $19(20)$ & $13(17)$ & $11(16)$ & $3(8)$ & 0.11 \\
\hline $\begin{array}{l}\text { No. of patients with distant } \\
\text { metastasis }\end{array}$ & $60(22)$ & $21(23)$ & $23(30)$ & 12 (17) & $4(10)$ & 0.084 \\
\hline $\begin{array}{l}\text { No. of patients with } \\
\text { postoperative biochemical } \\
\text { cure }^{\S}\end{array}$ & $48(20)$ & 12 (17) & $16(24)$ & 9 (15) & $10(31)$ & 0.32 \\
\hline
\end{tabular}

Numbers in parentheses denote the percentage of patients in the respective time period.

${ }^{\dagger}$ Excluding 18 patients $\left(6,10,2\right.$ and 0 patients) who had no pertinent information; ${ }^{\prime}$ Excluding 5 patients ( $2,3,0$ and 0 patients) who had no pertinent information; ${ }^{\S}$ Excluding 42 patients $(22,9,7$ and 4 patients) who had no raised calcitonin levels and/or no pertinent postoperative information. 
tomography, magnetic resonance imaging, 18-fluorodeoxyglucose or 18-fluoro-dopa positron emission tomography, or any combination thereof, regardless of whether it was noted at the initial operation, reoperation, or at any time during the follow-up. Biochemical cure was diagnosed when raised preoperative basal calcitonin levels had fallen below the upper normal limit of the calcitonin assay at last follow-up after the most recent (re-)operation at the authors' institution. Reports on follow-up treatment elsewhere were considered to obtain a comprehensive picture of clinical outcome, notably biochemical cure.

\section{Statistical analysis}

Categorical and continuous data were tested with the Fisher's exact test and one-way analysis of variance (ANOVA) respectively. Multiple testing was corrected for with the Bonferroni method as appropriate (25). The linear-by-linear association $\chi^{2}$ statistic was calculated to evaluate temporal trends of categorical variables. To ensure sufficiently large numbers of patients in each group, the year of initial neck surgery performed at the authors' institution or elsewhere was categorized in 5-year increments (2001-2005; 2006-2010; 20112015) against a 6-year baseline (1995-2000): Primary tumor size was grouped in $5-\mathrm{mm}$ increments $(\leq 10.0$; 10.1-20.0; 20.1-30.0; 30.1-40.0; >40.0 mm). For sensitivity analyses, the 322 patients treated first at the authors' institution were evaluated both together with, and separately from, the 278 patients treated first elsewhere. The level of significance (all tests were two-tailed) was set at $<0.05$.

\section{Results}

\section{Overall time trends of sporadic medullary thyroid cancer}

The number of patients with sporadic MTC referred for thyroidectomy to the authors' institution almost trebled from 38 (29\%) in 1995-2000 to 103 patients (73\%) in 2011-2015, while the number of patients referred after thyroidectomy elsewhere fell from 93 (71\%) to 39 patients (27\%; $P<0.001$; Table 1).

In the past two decades, from 1995-2000 to 20112015, there was also a large decline in the percentage of node-positive tumors (from 73 to 49\%), specifically mediastinal lymph node metastasis (from 21 to 6\%) and distant metastasis (from 23 to $6 \%$; all $P<0.001$ ). This fall was paralleled by significant increases in mean patient age (from 49.1 to 57.3 years) and the percentage of MTC $\leq 10 \mathrm{~mm}$ (from 19 to $39 \%$ ), and in biochemical cure rates (from 28 to $62 \%$; all $P<0.001$; Table 1 ).

In the subgroup of patients with MTC $\leq 10 \mathrm{~mm}$, the decreasing percentage of node-positive tumors (from 57 to $21 \% ; P=0.007$ ), specifically mediastinal lymph node metastasis (from 17 to $0 \% ; P=0.003$ ) and increasing biochemical cure rates (from 44 to $82 \% ; P=0.006$ ) remained statistically significant (data not shown).

In the subgroup of patients with MTC $>10 \mathrm{~mm}$, the diminishing percentage of mediastinal lymph node

Table 4 Time trends of biochemical cure by sporadic medullary thyroid cancer $\leq 10 \mathrm{~mm}$ vs $>10 \mathrm{~mm}$ and nodal status in patients treated first at the authors' institution. A total of 283 patients with complete data sets for each of the clinical variables examined were included in the analysis.

\begin{tabular}{|c|c|c|c|c|c|c|}
\hline \multirow[b]{2}{*}{ Patients with sporadic MTC } & \multirow[b]{2}{*}{ Total } & \multicolumn{4}{|c|}{ Period of initial thyroidectomy } & \multirow[b]{2}{*}{$P_{\text {trend }}$} \\
\hline & & $1995-2000$ & 2001-2005 & 2006-2010 & 2011-2015 & \\
\hline \multicolumn{7}{|l|}{$\leq 10 \mathrm{~mm}$} \\
\hline Node-negative, $n$ & 92 & 3 & 21 & 31 & 37 & \\
\hline Biochemical cure, $^{\dagger} n(\%)$ & $86(93)$ & $3(100)$ & $19(90)$ & $29(94)$ & $35(95)$ & 0.81 \\
\hline Node-positive, $n$ & 20 & 2 & 4 & 8 & 6 & \\
\hline Biochemical cure, $^{\dagger} n(\%)$ & $9(45)$ & $1(50)$ & $2(50)$ & $3(38)$ & $3(50)$ & $>0.99$ \\
\hline Total, $n$ & 112 & 5 & 25 & 39 & 43 & \\
\hline Biochemical cure, $^{\dagger} n(\%)$ & $95(85)$ & $4(80)$ & $21(84)$ & $32(82)$ & $38(88)$ & 0.56 \\
\hline \multicolumn{7}{|l|}{$>10 \mathrm{~mm}$} \\
\hline Node-negative, $n$ & 84 & 13 & 19 & 27 & 25 & \\
\hline Biochemical cure, $^{\dagger} n(\%)$ & $76(90)$ & $11(85)$ & $16(84)$ & $25(93)$ & $24(96)$ & 0.16 \\
\hline Node-positive, $n$ & 87 & 11 & 25 & 24 & 27 & \\
\hline Biochemical cure, $^{\dagger} n(\%)$ & $15(17)$ & $1(9)$ & $3(12)$ & $4(17)$ & $7(26)$ & 0.17 \\
\hline Total, $n$ & 171 & 24 & 44 & 51 & 52 & \\
\hline Biochemical cure, $^{\dagger} n(\%)$ & $91(53)$ & $12(50)$ & $19(43)$ & $29(57)$ & $31(60)$ & 0.18 \\
\hline
\end{tabular}


metastasis (from 36 to 8\%) and distant metastasis (from 24 to $10 \%$ ), and rising mean patient age (from 48.3 to 57.8years; all $P \leq 0.001)$ and improving biochemical cure rates (from 26 to $48 \% ; P=0.006$ ) were statistically significant (data not shown).

\section{Time trends of sporadic medullary thyroid cancer with thyroidectomy at the authors' institution}

The aforementioned time trends were mitigated in patients with thyroidectomy at the authors' institution, with preservation of the significant decline in the frequency of distant metastasis (from 24 to $5 \%$; $P<0.001$ ) after correction for multiple testing (Table 2).

In the subgroup of patients with MTC $\leq 10 \mathrm{~mm}$, no significant time trend became apparent (data not shown).

In the subgroup of patients with MTC $>10 \mathrm{~mm}$, mean age increased from 51.0 to 60.1 years $(P=0.003)$. At the same time, the percentage of mediastinal lymph node metastasis and distant metastasis decreased from 26 to $9 \%(P=0.041$; nonsignificant after correction for multiple testing) and from 30 to $9 \%(P=0.002)$ respectively (data not shown).

\section{Time trends of sporadic medullary thyroid cancer with thyroidectomy elsewhere}

In patients with thyroidectomy elsewhere, there was no significant time trend from 1995-2000 to 2011-2015 that survived correction for multiple testing (Table 3).

In the subgroup of patients with MTC $\leq 10 \mathrm{~mm}$, no significant time trend emerged.
In the subgroup of patients with MTC $>10 \mathrm{~mm}$, the percentage of extrathyroidal tumors rose from 18 to $41 \%$ $(P=0.007$; nonsignificant after correction for multiple testing; data not shown).

\section{Time trends of biochemical cure by sporadic medullary thyroid cancer $\leq 10 \mathrm{~mm}$ vs $>10 \mathrm{~mm}$ and nodal status}

For patients with thyroidectomy at the authors' institution, node-negative MTC conferred a 2- to 5-fold (93 vs $45 \%$ for MTC $\leq 10 \mathrm{~mm}$ and 90 vs $17 \%$ for MTC $>10 \mathrm{~mm}$ ) greater chance of achieving biochemical cure than node-positive MTC (Table 4).

In node-negative MTC, overall rates of biochemical cure were excellent at $90-100 \%$ for MTC $\leq 10 \mathrm{~mm}$ and increased modestly for MTC >10 mm: from $85 \%$ in 1995 2000 to $96 \%$ in $2011-2015(P=0.16)$.

In node-positive $\mathrm{MTC}$, overall rates of biochemical cure remained at $50 \%$ for MTC $\leq 10 \mathrm{~mm}$, and improved moderately for MTC >10 mm: from 9\% in 1995-2000 to $26 \%$ in 2011-2015 ( $P=0.17)$.

For patients with thyroidectomy elsewhere, nodenegative MTC carried a 4-fold (86 vs $22 \%$ for MTC $\leq 10 \mathrm{~mm}$ and $53 \mathrm{vs} 15 \%$ for MTC $>10 \mathrm{~mm}$ ) greater chance of reaching biochemical cure than node-positive MTC (Table 5).

In node-negative MTC, overall rates of biochemical cure approximated $100 \%$ for MTC $\leq 10 \mathrm{~mm}$ but were varied for MTC $>10 \mathrm{~mm}$, apparently owing to low numbers of patients in the groups.

Table 5 Time trends of biochemical cure by sporadic medullary thyroid cancer $\leq 10 \mathrm{~mm}$ vs $>10 \mathrm{~mm}$ and nodal status in patients treated first elsewhere.

\begin{tabular}{|c|c|c|c|c|c|c|}
\hline \multirow[b]{2}{*}{ Patients with sporadic MTC } & \multirow[b]{2}{*}{ Total } & \multicolumn{4}{|c|}{ Period of initial thyroidectomy } & \multirow[b]{2}{*}{$\boldsymbol{P}_{\text {trend }}$} \\
\hline & & $1995-2000$ & 2001-2005 & $2006-2010$ & 2011-2015 & \\
\hline \multicolumn{7}{|l|}{$\leq 10 \mathrm{~mm}$} \\
\hline Node-negative, $n$ & 7 & 1 & 2 & 1 & 3 & \\
\hline Biochemical cure, ${ }^{\dagger} n(\%)$ & $6(86)$ & $1(100)$ & $2(100)$ & $1(100)$ & $2(67)$ & $>0.99$ \\
\hline Node-positive, $n$ & 23 & 10 & 5 & 3 & 5 & \\
\hline Biochemical cure, $^{\dagger} n(\%)$ & $5(22)$ & $2(20)$ & $0(0)$ & $1(33)$ & $2(40)$ & 0.41 \\
\hline Total, $n$ & 30 & 11 & 7 & 4 & 8 & \\
\hline Biochemical cure, ${ }^{\dagger} n(\%)$ & $11(37)$ & $3(27)$ & $2(29)$ & $2(50)$ & $4(50)$ & 0.29 \\
\hline \multicolumn{7}{|l|}{$>10 \mathrm{~mm}$} \\
\hline Node-negative, $n$ & 17 & 4 & 10 & 1 & 2 & \\
\hline Biochemical cure, $^{\dagger} n(\%)$ & $9(53)$ & $1(25)$ & $6(60)$ & $0(0)$ & $2(100)$ & 0.29 \\
\hline Node-positive, $n$ & 174 & 52 & 42 & 55 & 25 & \\
\hline Biochemical cure, $^{\dagger} n(\%)$ & $26(15)$ & $8(15)$ & $6(14)$ & $7(13)$ & $5(28)$ & 0.84 \\
\hline Total, $n$ & 191 & 56 & 52 & 56 & 27 & \\
\hline Biochemical cure, $^{\dagger} n(\%)$ & 35 (18) & $9(16)$ & $12(23)$ & $7(13)$ & $7(26)$ & 0.72 \\
\hline
\end{tabular}


Table 6 Multivariate logistic regression on biochemical cure ${ }^{\dagger}$ of sporadic medullary thyroid cancer.

\begin{tabular}{|c|c|c|c|}
\hline Independent variable & $\begin{array}{c}\text { No. of } \\
\text { patients* }\end{array}$ & $\begin{array}{l}\text { Odds ratio } \\
{[95 \% \mathrm{Cl}]}\end{array}$ & $\boldsymbol{P}$ \\
\hline $\begin{array}{l}\text { Nodal status: negative } \\
\quad \text { (vs positive) }\end{array}$ & 200 vs 304 & $22.1[12.4 ; 39.2]$ & $<0.001$ \\
\hline $\begin{array}{l}\text { Primary tumor diameter: } \\
\quad \leq 10 \mathrm{~mm} \text { (vs }>10 \mathrm{~mm})\end{array}$ & 142 vs 362 & $2.3[1.3 ; 4.1]$ & 0.006 \\
\hline $\begin{array}{l}\text { Clinical presentation: } \\
\text { initial surgery } \\
\text { (vs reoperation) }\end{array}$ & 283 vs 221 & $1.9[1.1 ; 3.2]$ & 0.026 \\
\hline \multicolumn{4}{|l|}{ Period of thyroidectomy: } \\
\hline 2011-2015 & 130 & $1.8[0.8 ; 3.9]$ & 0.14 \\
\hline $2006-2010$ & 150 & $1.2[0.6 ; 2.6]$ & 0.61 \\
\hline 2001-2005 & 128 & $0.9[0.4 ; 1.9]$ & 0.76 \\
\hline (vs 1995-2000) & 96 & 1 & - \\
\hline
\end{tabular}

*A total of 504 patients with complete data sets for each of the clinical variables examined were included in the analysis; ${ }^{+}$Preoperatively raised calcitonin levels falling below the upper normal limit of the calcitonin assay after surgery.

In node-positive MTC, overall rates of biochemical cure were $20-40 \%$ for MTC $\leq 10 \mathrm{~mm}$, and improved moderately in MTC >10 mm: from $15 \%$ in $1995-2000$ to $28 \%$ in 2011-2015 $(P=0.84)$.

Patients with thyroidectomy at the authors' institution (Table 4), as compared with patients with thyroidectomy elsewhere (Table 5), reached biochemical cure more often: 85 vs $37 \%$ for MTC $\leq 10 \mathrm{~mm}$ and 53 vs $18 \%$ for MTC $>10 \mathrm{~mm}$.

In node-negative MTC, these rates were 93 vs $86 \%$ for MTC $\leq 10 \mathrm{~mm}$ and 90 vs $53 \%$ for MTC $>10 \mathrm{~mm}$.

In node-positive MTC, these rates were 45 vs $22 \%$ for MTC $\leq 10 \mathrm{~mm}$ and $17 \mathrm{vs} 15 \%$ for MTC $>10 \mathrm{~mm}$.

There was no evidence in these data to suggest that sporadic MTC $\leq 10 \mathrm{~mm}$, specifically node-negative MTC, may represent a tumor entity of its own that would set it apart from larger sporadic MTC.

\section{Multivariate logistic regression on biochemical cure}

A multivariate logistic regression model (Table 6) was fitted to quantify the independent contributions of nodal status (negative vs positive), primary tumor diameter ( $\leq 10 \mathrm{~mm}$ vs $>10 \mathrm{~mm}$ ), clinical presentation (initial surgery vs reoperation at the authors' institution), and period of thyroidectomy on postoperative biochemical cure. In that model, negative nodal status (odds ratio [OR] 22.1) was the overwhelming predictive factor of postoperative biochemical cure, leaving MTC $\leq 10 \mathrm{~mm}$ (OR 2.3) and initial surgery (OR 1.9) far behind. Because the period of thyroidectomy had no appreciable impact on surgical cure, there was no indication of time bias.

\section{Discussion}

The present time trends, possibly reflecting greater uptake of calcitonin screening by patients with nodular thyroid disease on top of the gold standard of neck ultrasonography, have transformed the landscape of sporadic MTC in Germany. In the course of time, more patients were referred for initial surgery to the authors' institution as the importance of systematic lymph node dissection for surgical control of sporadic MTC $(18,26)$ became evident (Table 1). With the expansion of routine calcitonin screening, more elderly segments of the population were captured so that patient age rose by a mean of 8.2 (from 49.1 to 57.3 ) years in a 21-year stretch. At the same time, more localized sporadic MTC appeared to have been detected and cured surgically over time.

Noteworthy findings were obtained in two mixed series of 109 and 331 Korean patients with mainly sporadic MTC respectively $(27,28)$ : Mean patient age increased from 44.1 years in $1996-2000$ to 53.8 years in 2007-2011 ( $P=0.005)$, and from 40.5 years in $1982-2000$ to 50.5 years in 2011-2012 $(P<0.001)$ respectively. In the smaller series, the percentage of MTC $\leq 10 \mathrm{~mm}$ reportedly rose from 0 to $45 \%(P=0.001)$. Although mean primary tumor size in the Korean series significantly $(P \leq 0.002)$ decreased from $31 \mathrm{~mm}$ in $1996-2000$ to $18 \mathrm{~mm}$ in 2007-2011 (27), and from $25 \mathrm{~mm}$ in 1982-2000 to $17 \mathrm{~mm}$ in 2011-2012 (28), a similar, though attenuated, reduction in primary tumor size was observed only for the 322 patients treated first at the authors' institution (from $26.1 \mathrm{~mm}$ in $1995-2000$ to $19.7 \mathrm{~mm}$ in $2011-2015$; $P=0.018$; Table 2). Likewise, this decrease was paralleled by a corresponding surge of MTC $\leq 10 \mathrm{~mm}$ (from $23 \%$ in 1995-2000 to 45\% in 2011-2015; $P=0.037$; Table 2). These differences in effect size, which were stronger in the Korean series, may reflect the more recent access of the Korean, as compared with the German, population to comprehensive health care.

Based on an MTC prevalence of 1 in 30000 inhabitants, $25 \%$ of which are thought to have hereditary MTC, and a total population of 80 million inhabitants, 2000 patients with sporadic MTC are estimated to live in Germany (1:30000 times 0.75\% times 80000000$)$. Accordingly, our 600 patients should account for $30 \%$ of the German sporadic MTC population. 


\section{Anatomic imaging vs biochemical screening}

In diagnostic imaging, the ability to detect a structural abnormality is closely related to the size of that abnormality (29) and interference by concurrent abnormal thyroid morphology ('background noise'). Nodular thyroid disease is more prevalent in iodine-deficient or barely iodinesufficient countries like Germany (30). The addition of biochemical screening with more sensitive calcitonin assays to anatomic imaging may have contributed to diminish the numbers of patients with metastatic MTC in the new millennium.

The interrelationship between size (greater tumors being more easily spotted than smaller tumors), detection threshold (calcitonin screening being more sensitive than high-resolution ultrasonography), and disease prevalence (being a function of size and detection threshold) may explain the surge in the number of patients diagnosed with sporadic MTC, peaking in 2006-2010. These findings, mirroring the increase in newly identified gene carriers at risk of hereditary MTC with the advent of DNA-based screening in the 1990s (31), may be attributable, at least in part, to the superiority of biochemical over anatomic screening in detecting sporadic MTC in the context of nodular thyroid disease.

The fast expansion of biochemical (calcitonin) screening for sporadic MTC conceivably can be likened to the rapid uptake of biochemical (prostate-specific antigen; PSA) screening for prostate cancer. PSA screening resulted in a spike in overall prostate cancer diagnoses during the early 1990s (32), which was followed by a decline in the incidence of metastatic disease (2) and reduction of the risk of death from prostate cancer by about one-fifth (33). Such a decline of metastatic disease was also seen for sporadic MTC in the present series.

\section{Limitations of the study}

This investigation was limited by its retrospective study design and the time span covered. It was not designed to estimate time to recurrence or distant metastasis, which would necessitate standardization of the initial operation and follow-up investigations as to frequency and type of imaging.

Because the number of all patients with nodular thyroid disease screened biochemically is unknown, the effect of the 2004 German Society for Endocrinology Thyroid Group (11) and 2006 interdisciplinary European consensus (12) recommendations for calcitonin screening in nodular thyroid disease cannot be assessed directly, hampering estimation of the effects of screening.

Although total thyroidectomy with central and lateral lymph node dissection had been performed at the authors' institution in 92 and $83 \%$ of our 600 patients, biochemical cure was not attained in all patients with intrathyroidal, node-negative MTC. These patients revealed postoperative calcitonin levels fluctuating around, or barely exceeding, the upper normal limit of the calcitonin assay even after extended periods of follow-up. Thus it cannot be ruled out that occult thyroid tissue, harboring sufficient quantities of normal calcitonin-secreting parafollicular C-cells to mimic persistent disease (false-positive test result), may have been left behind in some patients. This is why surgical cure may have been accomplished more often in this study than suggested by the failure to reach normal postoperative calcitonin serum levels. Removal of all gross thyroid tissue is less easily effected on reoperation than at the initial operation, which may have contributed to the worse biochemical cure rates after reoperation (Table 5 as compared with Table 4). On a cautionary note, findings obtained at a high-volume specialist center may not be generalizable to other clinical settings. After initial biochemical cure, postoperative basal calcitonin serum levels rarely climb again above the upper normal limit of the calcitonin assay, which a French national registry analysis reported for 15 (3.3\%) of its 453 patients some 3.2 years after surgery (34).

Unless one can follow a cohort over time, there is no way of accurately estimating the probability that a subclinical detected abnormality (i.e., node-negative occult sporadic MTC) will naturally progress to an adverse outcome (i.e., become node-positive) (29). This is a recognized limitation of any screening program. Disease detected by testing tends to progress less rapidly than disease that would ultimately present clinically in the absence of testing. These cases may regress, remain stable, or progress too slowly to become clinically apparent during the patient's lifetime (29).

\section{Conclusion}

Notwithstanding these considerations, the significant reduction in mediastinal lymph node metastasis and distant metastasis in conjunction with the corresponding rise in biochemical cure rates among patients with sporadic MTC $>10 \mathrm{~mm}$ brought about increasing therapeutic tumor control over time. Because increasingly more sophisticated anatomic imaging technologies have found in the past, and will continue to find in the future, 
their way into clinical practice, the independent effects of routine biochemical screening for sporadic MTC remain hard to define - a challenge also encountered by many biochemical screening programs for other types of cancer. The higher rate of routine biochemical screening in patients with thyroidectomy at the authors' institution, as compared with patients with thyroidectomy elsewhere, arguably may have contributed to reducing primary tumor size at first surgery (means of $19.1 \mathrm{vs} 25.0 \mathrm{~mm}$; Tables 2 and 3) by intervening earlier on the tumor's growth trajectory. Biochemical cure rates were consistently better in the former than the latter patient subgroup (64 vs 20\%; Tables 2 and 3), and superior for node-negative MTC as compared with node-positive MTC within these subgroups (Tables 4 and 5).

Because more extensive surgery at incremental morbidity did not manage to improve biochemical cure rates further, as illustrated in Tables 4 and 5, early detection of small sporadic MTC, ideally as long as it is still nodenegative, takes center stage. Literature data argue against portraying node-positive MTC $\leq 10 \mathrm{~mm}$, unlike papillary thyroid microcarcinoma, as an innocuous tumor entity in its own right not worthwhile operating on $(35,36)$. Irrespective of time period, positive nodal status remained the key driver of persistent disease (Table 6). In keeping with this, the presence of 10 and more lymph node metastases is inconsistent with surgical cure $(37,38)$.

Because primary tumor size correlates with lymphatic spread and distant metastasis (18), it is reasonable to assume that earlier detection can enhance clinical outcome further, taking surgical cure rates in MTC to a higher level. The present biochemical cure rates of $90-100 \%$ for nodenegative MTC $\leq 10 \mathrm{~mm}$ (Table 4) support that notion.

\section{Declaration of interest}

The authors declare that there is no conflict of interest that could be perceived as prejudicing the impartiality of the research reported.

\section{Funding}

This research did not receive any specific grant from any funding agency in the public, commercial or not-for-profit sector.

\section{References}

1 Borget I, De Pouvourville G \& Schlumberger M. Editorial: calcitonin determination in patients with nodular thyroid disease. Journal of Clinical Endocrinology and Metabolism 200792 425-427. (doi:10.1210/ jc.2006-2735)

2 Welch HG, Gorski DH \& Albertsen PC. Trends in metastatic breast and prostate cancer - lessons in cancer dynamics. New
England Journal of Medicine 2015373 1685-1687. (doi:10.1056/ nejmp1510443)

3 Davies L \& Welch HG. Increasing incidence of thyroid cancer in the United States, 1973-2002. Journal of the American Medical Association 2006295 2164-2167. (doi:10.1001/jama.295.18.2164)

4 Dralle H, Machens A, Basa J, Fatourechi V, Franceschi S, Hay ID, Nikiforov YE, Pacini F, Pasieka JL \& Sherman SI. Follicular cell-derived thyroid cancer. Nature Reviews Disease Primers 20151 15077. (doi:10.1038/nrdp.2015.77)

5 Machens A, Lorenz K \& Dralle H. Progression of medullary thyroid cancer in RET carriers of ATA class A and C mutations. Journal of Clinical Endocrinology and Metabolism 201499 E286-E292. (doi:10.1210/jc.2013-3343)

6 Pacini F, Fontanelli M, Fugazzola L, Elisei R, Romei C, Di Coscio G, Miccoli P \& Pinchera A. Routine measurement of serum calcitonin in nodular thyroid diseases allows the preoperative diagnosis of unsuspected sporadic medullary thyroid carcinoma. Journal of Clinical Endocrinology and Metabolism 199478 826-829. (doi:10.1210/ jc.78.4.826)

7 Rieu M, Lame MC, Richard A, Lissak B, Sambort B, Vuong-Ngoc P, Berrod JL \& Fombeur JP. Prevalence of sporadic medullary thyroid carcinoma: the importance of routine measurement of serum calcitonin in the diagnostic evaluation of thyroid nodules. Clinical Endocrinology 199542 453-460. (doi:10.1111/j.1365-2265.1995. tb02662.x)

8 Niccoli P, Wion-Barbot N, Caron P, Henry JF, de Micco C, Saint Andre JP, Bigorgne JC, Modigliani E, Conte-Devolx B \& French Medullary Study Group. Interest of routine measurement of serum calcitonin: study in a large series of thyroidectomized patients. Journal of Clinical Endocrinology and Metabolism 199782 338-341. (doi:10.1210/jcem.82.2.3737)

9 Vierhapper H, Raber W, Bieglmayer C, Kaserer K, Weinhäusl A \& Niederle B. Routine measurement of plasma calcitonin in nodular thyroid diseases. Journal of Clinical Endocrinology and Metabolism 1997 82 1589-1593. (doi:10.1210/jc.82.5.1589)

10 Cheung K, Roman SA, Wang TS, Walker HD \& Sosa JA. Calcitonin measurements in the evaluation of thyroid nodules in the United States: a cost-effectiveness and decision analysis. Journal of Clinical Endocrinology and Metabolism 200893 2173-2180. (doi:10.1210/ jc.2007-2496)

11 Karges W, Dralle H, Raue F, Mann K, Reiners C, Grussendorf M, Hüfner M, Niederle B, Brabant G \& German Society for Endocrinology (DGE) - Thyroid Section. Calcitonin measurement to detect medullary thyroid carcinoma in nodular goiter: German evidence-based consensus recommendations. Experimental and Clinical Endocrinology \& Diabetes 2004112 52-58. (doi:10.1055/s-2004-815727)

12 Pacini F, Schlumberger M, Dralle H, Elisei R, Smit JW, Wiersinga W $\&$ European Thyroid Cancer Taskforce. European consensus for the management of patients with differentiated thyroid carcinoma of the follicular epithelium. European Journal of Endocrinology $2006 \mathbf{1 5 4}$ 787-803. (doi:10.1530/eje.1.02158)

13 Wells SA Jr, Asa SL, Dralle H, Elisei R, Evans DB, Gagel RF, Lee N, Machens A, Moley JF, Pacini F et al. Revised American Thyroid Association guidelines for the management of medullary thyroid carcinoma. Thyroid 201525 567-610. (doi:10.1089/thy.2014.0335)

14 Costante G, Meringolo D, Durante C, Bianchi D, Nocera M, Tumino S, Crocetti U, Attard M, Maranghi M, Torlontano M et al. Predictive value of serum calcitonin levels for preoperative diagnosis of medullary thyroid carcinoma in a cohort of 5817 consecutive patients with thyroid nodules. Journal of Clinical Endocrinology and Metabolism 200792 450-455. (doi:10.1210/jc.2006-1590)

15 Elisei R, Bottici V, Luchetti F, Di Coscio G, Romei C, Grasso L, Miccoli P, Iacconi P, Basolo F, Pinchera A et al. Impact of routine measurement of serum calcitonin on the diagnosis and outcome of medullary thyroid cancer: experience in 10,864 patients with nodular 
thyroid disorders. Journal of Clinical Endocrinology and Metabolism 200489 163-168. (doi:10.1210/jc.2003-030550)

16 Morris LF, Waguespack SG, Edeiken-Monroe BS, Lee JE, Rich TA, Ying AK, Warneke CL, Evans DB, Perrier ND \& Grubbs EG. Ultrasonography should not guide the timing of thyroidectomy in pediatric patients diagnosed with multiple endocrine neoplasia syndrome $2 \mathrm{~A}$ through genetic screening. Annals of Surgical Oncology 201320 53-59. (doi:10.1245/s10434-012-2589-7)

17 Dralle H. [Malignant thyroid tumors]. In Deutsche Krebsgesellschaft e. V. [Abbreviated Interdisciplinary Guidelines 2006. Recommendations for Diagnosis and Therapy of Malignant Diseases]. Eds C Garbe, P Albers, MW Beckmann, C Bokemeyer, F Bootz, U Creutzig, P Drings, HE Gabbert, H Heimpel, W Hohenberger et al. W. Zuckschwerdt Verlag Munich, Vienna, New York 2006 [in German].

18 Machens A \& Dralle H. Biomarker-based risk stratification for previously untreated medullary thyroid cancer. Journal of Clinical Endocrinology and Metabolism 201095 2655-2663. (doi:10.1210/jc.2009-2368)

19 Machens A \& Dralle H. Benefit-risk balance of reoperation for persistent medullary thyroid cancer. Annals of Surgery 2013257 751-757. (doi:10.1097/SLA.0b013e31826bc239)

20 Machens A, Lorenz K \& Dralle H. Individualization of lymph node dissection in RET (rearranged during transfection) carriers at risk for medullary thyroid cancer: value of pretherapeutic calcitonin levels. Annals of Surgery 2009250 305-310. (doi:10.1097/ SLA.0b013e3181ae333f)

21 Dralle H, Damm I, Scheumann GFW, Kotzerke J, Kupsch E, Geerlings H \& Pichlymayr R. Compartment-oriented microdissection of regional lymph nodes in medullary thyroid carcinoma. Surgery Today 199424 112-121. (doi:10.1007/BF02473391)

22 Dralle H. Lymph node dissection and medullary thyroid carcinoma. British Journal of Surgery 200289 1073-1075. (doi:10.1046/j.13652168.2002.02160.x)

23 Hedinger C, Williams ED \& Sobin LH. Histological typing of thyroid tumours, 2nd ed., No. 11. In International Histological Classification of Tumours, 2nd ed. Geneva, Switzerland: World Health Organisation/Berlin, Heidelberg, New York, London, Tokyo, Hong Kong: Springer, 1988.

24 DeLellis RA, Lloyd RV, Heitz PU \& Eng C, eds. World Health Organization Classification of Tumours: Pathology and Genetics of Tumours of Endocrine Organs. Lyon, France: IARC Press, 2004.

25 Bland JM \& Altman DG. Multiple significance tests: the Bonferroni method. British Medical Journal 1995310 170. (doi:10.1136/ bmj.310.6973.170)

26 Machens A \& Dralle H. Prognostic impact of N staging in 715 medullary thyroid cancer patients: proposal for a revised staging system. Annals of Surgery 2013257 323-329. (doi:10.1097/ SLA.0b013e318268301d)

27 Kwon H, Kim WG, Sung TY, Jeon MJ, Song DE, Lee YM, Yoon JH, Chung KW, Hong SJ, Baek JH et al. Changing trends in the clinicopathological features and clinical outcomes of medullary thyroid carcinoma. Journal of Surgical Oncology 2016113 152-158. (doi:10.1002/jso.v113.2)

28 Jung KY, Kim SM, Yoo WS, Kim BW, Lee YS, Kim KW, Lee KE, Jeong JJ, Nam KH, Lee SH et al. Postoperative biochemical remission of serum calcitonin is the best predictive factor for recurrence-free survival of medullary thyroid cancer: a large-scale retrospective analysis over 30 years. Clinical Endocrinology 201684 587-597. (doi:10.1111/ cen.2016.84.issue-4)

29 Black WC \& Welch HG. Advances in diagnostic imaging and overestimations of disease prevalence and the benefits of therapy. New England Journal of Medicine 1993328 1237-1243. (doi:10.1056/ nejm199304293281706)

30 Völzke H, Lüdemann J, Robinson DM, Spieker KW, Schwahn C, Kramer A, John U \& Meng W. The prevalence of undiagnosed thyroid disorders in a previously iodine-deficient area. Thyroid $2003 \mathbf{1 3}$ 803-810. (doi:10.1089/105072503768499680)

31 Machens A \& Dralle H. Therapeutic effectiveness of screening for multiple endocrine neoplasia type 2A. Journal of Clinical Endocrinology and Metabolism 2015100 2539-2545. (doi:10.1210/jc.2015-1689)

32 Welch HG \& Albertsen PC. Prostate cancer diagnosis and treatment after the introduction of prostate-specific antigen screening: 19862005. Journal of the National Cancer Institute 2009101 1325-1329. (doi:10.1093/jnci/djp278)

33 Schröder FH, Hugosson J, Roobol MJ, Tammela TL, Ciatto S, Nelen V, Kwiatkowski M, Lujan M, Lilja H, Zappa M et al. Prostate-cancer mortality at 11 years of follow-up. New England Journal of Medicine 2012366 981-990. (doi:10.1056/NEJMoa1113135)

34 Franc S, Niccoli-Sire P, Cohen R, Bardet S, Maes B, Murat A, Krivitzky A \& Modigliani E \& French Medullary Study Group (GETC). Complete surgical lymph node resection does not prevent authentic recurrences of medullary thyroid carcinoma. Clinical Endocrinology 200155 403-409. (doi:10.1046/j.1365-2265.2001.01339.x)

35 Kazaure HS, Roman SA \& Sosa JA. Medullary thyroid microcarcinoma. A population-level analysis of 310 patients. Cancer 2012118 620-627. (doi:10.1002/cncr.26283)

36 Machens A \& Dralle H. Biological relevance of medullary thyroid microcarcinoma. Journal of Clinical Endocrinology and Metabolism 2012 97 1547-1553. (doi:10.1210/jc.2011-2534)

37 Machens A, Gimm O, Ukkat J, Hinze R, Schneyer U \& Dralle H. Improved prediction of calcitonin normalization in medullary thyroid carcinoma patients by quantitative lymph node analysis. Cancer 200088 1909-1915. (doi:10.1002/(sici)1097. 0142(20000415)88:8<1909::aid-cncr21>3.3.co;2-1)

38 Scollo C, Baudin E, Travagli JP, Caillou B, Bellon N, Leboulleux S \& Schlumberger M. Rationale for central and bilateral lymph node dissection in sporadic and hereditary medullary thyroid cancer. Journal of Clinical Endocrinology and Metabolism 200388 2070-2075. (doi:10.1210/jc.2002-021713)

Received 10 April 2016

Revised version received 31 May 2016

Accepted 21 June 2016 